Annals of Warsaw University of Life Sciences - SGGW

Land Reclamation No 38, 2007: 95-104

(Ann. Warsaw Univ. of Life Sci. - SGGW, Land Reclam. 38, 2007)

\title{
Possible effects of climate change on ecological functioning of shallow lakes, Lake Loenderveen as a case study
}

\author{
SEBASTIAAN A. SCHEP ${ }^{1}$, GERARD N.J. TER HEERDT ${ }^{2}$, JAN H. JANSE ${ }^{3}$, \\ MAARTEN OUBOTER ${ }^{2}$ \\ ${ }^{1}$ Witteveen+Bos, The Netherlands \\ ${ }^{2}$ Waternet, The Netherlands \\ ${ }^{3} \mathrm{MNP} / \mathrm{NLB}$, The Netherlands
}

\begin{abstract}
Possible effects of climate change on ecological functioning of shallow lakes, Lake Loenderveen as a case study. The European Water Framework Directive (WFD) requires all inland and coastal waters to reach "good ecological status" by 2015 . The good ecological status of shallow lakes can be characterised by clear water dominated by submerged vegetation. The ecological response of shallow lakes on nutrients largely depends on morphological and hydrological features, such as water depth, retention time, water level fluctuations, bottom type, fetch etc. These features determine the "critical nutrient load" of a lake. When the actual nutrient load of a lake is higher than the critical nutrient load, the ecological quality of this lake will deteriorate, resulting in a turbid state dominated by algae. Climate change might lead to changes in both environmental factors and ecosystem response. This certainly will have an effect on the ecological status. As an illustration the results of a multidiscipline study of a shallow peaty lake (Loenderveen) are presented, including hydrology, geochemistry and ecology. Ground- and surface water flows, nutrient dynamics and ecosystem functioning have been studied culminating in an application of the ecological model of the lake (PCLake). Future scenarios were implemented through changing precipitation, evaporation and temperature. Climate change will lead to higher nutrient loads and lower critical nutrient loads. As a consequence lakes shift easier from clear water to a turbid state.
\end{abstract}

Key words: shallow lakes, climatic change, PCLake model, nutrient load.

\section{INTRODUCTION}

The European Water Framework Directive (WFD) requires all inland and coastal waters to reach "good ecological status" ultimately in 2027. In general, a shallow lake in good ecological condition can be characterised by clear water, small amounts of phytoplankton, vegetation dominated by submerged vegetation and rich (macro) invertebrate and fish communities (Scheffer, 2001).

The actual ecological state (clear or turbid) of shallow lakes largely depends on the actual nutrient load and the "critical nutrient load". The critical nutrient load is the nutrient load needed to make a clear lake become turbid and vice versa. Because of hysteresis processes two critical nutrient loads (CNL) can be defined (Scheffer, 2001). The shift from clear to turbid (eutophication, $\mathrm{CNL}_{\mathrm{eu}}$ ) often occurs at a much higher nutrient load than the switch back from turbid to clear (oligotrophication, $\mathrm{CNL}_{\text {oligo }}$ ). When the nutrient load is below $\mathrm{CNL}_{\text {oligo }}$ the lake is stably clear, when the load is above $\mathrm{CNL}_{\text {eu }}$ the lake is stably turbid (Fig. 1). In the intermediate range, both states may exist and switches between the two 


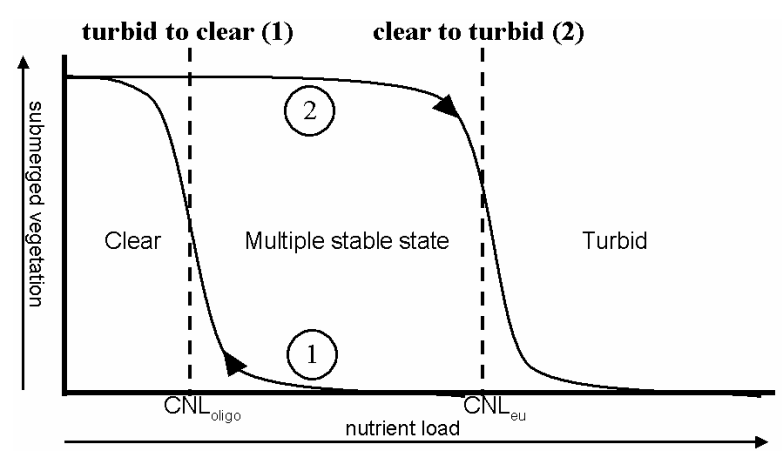

FIGURE 1. Critical nutrient loads of shallow lakes related to submerged vegetation

states are possible (multiple stable state (Scheffer et al., 1993; Scheffer, 2001)).

The critical nutrient load depends on morphological features (water depth, soil type and lake size), hydrological features (ground- and surface water flow, retention time, water level fluctuations) and climate conditions (water temperature). The actual nutrient load depends on climate conditions (precipitation, evaporation) and environmental conditions (water quality).

Most shallow lakes in the Netherlands are in the turbid, eutrophic state (Gulati and van Donk, 2002). Because of mostly food-web related self-stabilizing mechanisms (see e.g. Scheffer, 1998) restoration measures mainly aimed at reducing the nutrient load did not succeed. Therefore other approaches are needed. Instead of reducing the nutrient load, the critical nutrient load can be increased by changing system characteristics or when the nutrient load is in the intermediate range biomanipulation can be a preferable measure (Gulati and Van Donk, 2002).

Climate change might lead to changes in both environmental factors and ecosystem response. Hydraulic and nutrient load will increase with increasing precipitation (Mooij et al., 2005).
Chemical and bacteriological processes and the growth rates of phytoplankton and submerged vegetation increase when temperature increases (Mooij et al., 2005; Mooij et al., 2007).

Each individual lake will be differently affected by climate change. In general, the critical nutrient loads, $\mathrm{CNL}_{\text {oligo }}$ and $\mathrm{CNL}_{\mathrm{eu}}$ might likely decrease with increasing temperature and precipitation (Mooij et al., 2005). The decrease of $\mathrm{CNL}_{\mathrm{eu}}$ combined with an increase of the nutrient load might cause a clear lake to become turbid, while a decreased $\mathrm{CNL}_{\text {oligo }}$ will hamper the return towards the clear state. Therefore, to determine realistic and sustainable goals and measures for the WFD, water quality managers should take climate change into account.

The main goal of this study is to relate effects of climate change to the ecological functioning of Lake Loenderveen. Further a methodology to study the potential effect of climate change on lake ecosystems is developed and tested.

Ground- and surface water flows, nutrient dynamics and ecosystem functioninghavebeenstudiedculminating in an application of the ecological model 
PCLake. A nutrient balance is used to predict effects of climate change on the nutrient load. PCLake is used to predict effects of climate change on the critical nutrient load.

\section{METHODS}

This study is focused on the isolated and mainly rainwater fed Lake Loenderveen, part of the Loosdrecht Lakes system in the Netherlands (Fig. 2). The lake is oval shaped. Some characteristics: the size is $237 \mathrm{ha}$, the fetch is $1540 \mathrm{~m}$, the mean depth is $2.31 \mathrm{~m}$ and the residence time is $>1.5$ years. The bottom is peaty; with $10 \%$ dry matter, containing $58 \%$ organic matter and $12 \%$ lutum. Organic matter is mainly detritus (90\%). Until 1984 the water was clear and large areas were covered with submerged vegetation (Best et al., 1994). In 1987 the water had become turbid (Dekker et al., 1992) and all submerged vegetation had been gone.

The ecological status of the lake is predicted by the ecological lake model PCLake. The framework of the model is defined by an accurate water and nutrient balance. Because inlet and outlet of water in Lake Loenderveen is partly depended
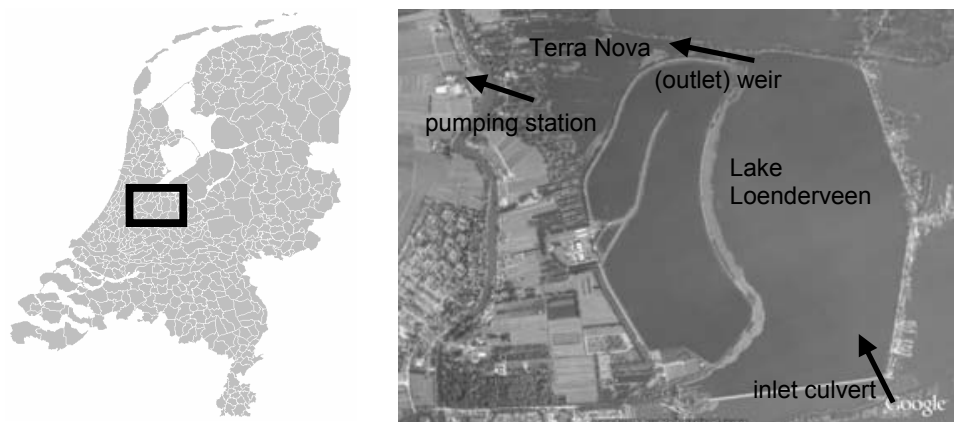

FIGURE 2. Lake Loenderveen (Google Earth 2005) on the water balance of the adjacent lake Terra Nova, Terra Nova (water surface 89.5 ha, average depth $1.43 \mathrm{~m}$, residence time 0.5 year) is included in the water and nutrient balance. The studied period is from 1970 to 2004, because of important historical nutrient loads.

The hydrology of both lakes is simple. Precipitation and evaporation dominate the water balance, because of the isolated position of the lakes. Groundwater influence is almost negligible. During water shortage of Lake Loenderveen or Terra Nova, water is supplied from the adjacent Lake Loosdrecht via an inlet culvert in the south. When the water level is high in either Lake Loenderveen or Terra Nova, water is pumped to the river Vecht through a pumping station. Since 1973 Lake Loenderveen and Terra Nova are separated through a weir. Water passes the weir during high water levels in Lake Loenderveen or water shortage in Terra Nova.

Precipitation and evaporation data were collected from the Royal Netherlands Meteorological Institute, weather station De Bilt. Water levels of Lake Loenderveen, Terra Nova and its adjacent lakes were measured. Seepage and infiltration in both Terra Nova and Lake Loenderveen were modelled with 
the Multi Layer Analytical Element Model MLAEM (de Lange, 1991) and appeared to be a linear function of the difference between the water levels of the adjacent lakes and Lake Loenderveen and Terra Nova. Discharges through weir, culvert and outlet were estimated as the water surplus and water shortage respectively, and compared to the measured in and outlet.

The water balance was validated with the chloride balance. Chloride concentrations are measured in inlet water and lake water and estimated in precipitation and seepage water as 6 $\mathrm{mg} \cdot \mathrm{l}^{-1}$ and $25 \mathrm{mg} \cdot \mathrm{l}^{-1}$ respectively.

The nutrient balance is mainly focused on phosphorus $(\mathrm{P})$, as on average $\mathrm{P}$ is the limiting nutrient for algae and water plant production. Concentrations of total $\mathrm{P}$ in inlet water and lake water were measured. Concentrations of $\mathrm{P}$ in precipitation and seepage water were estimated as $0.02 \mathrm{mg} \cdot \mathrm{l}^{-1}$ and $0.1 \mathrm{mg} \cdot \mathrm{l}^{-1}$ respectively. PCLake calculates P release from the sediment. Nitrogen fluxes are less important in Lake Loenderveen. Based on measurements, the NP-ratio in PCLake was set to 34.

PCLake is a mathematical, deterministic, zero dimensional, process based, integrated ecosystem lake model (Fig. 3). The model has been calibrated on more than 40 mainly Dutch lakes and a systematic sensitivity and uncertainty analysis has been performed (Aldenberg et al., 1995; Janse, 2005).

The aim of PCLake is to analyze the probability of a transition from a clear water (dominated by submerged vegetation) to a turbid water state (dominated by phytoplankton), or vice versa, as a function of the external nutrient loading and other factors (Janse, 2005). With PCLake the critical nutrient loads, $\mathrm{CNL}_{\mathrm{eu}}$ and $\mathrm{CNL}_{\text {oligo }}$, are estimated,

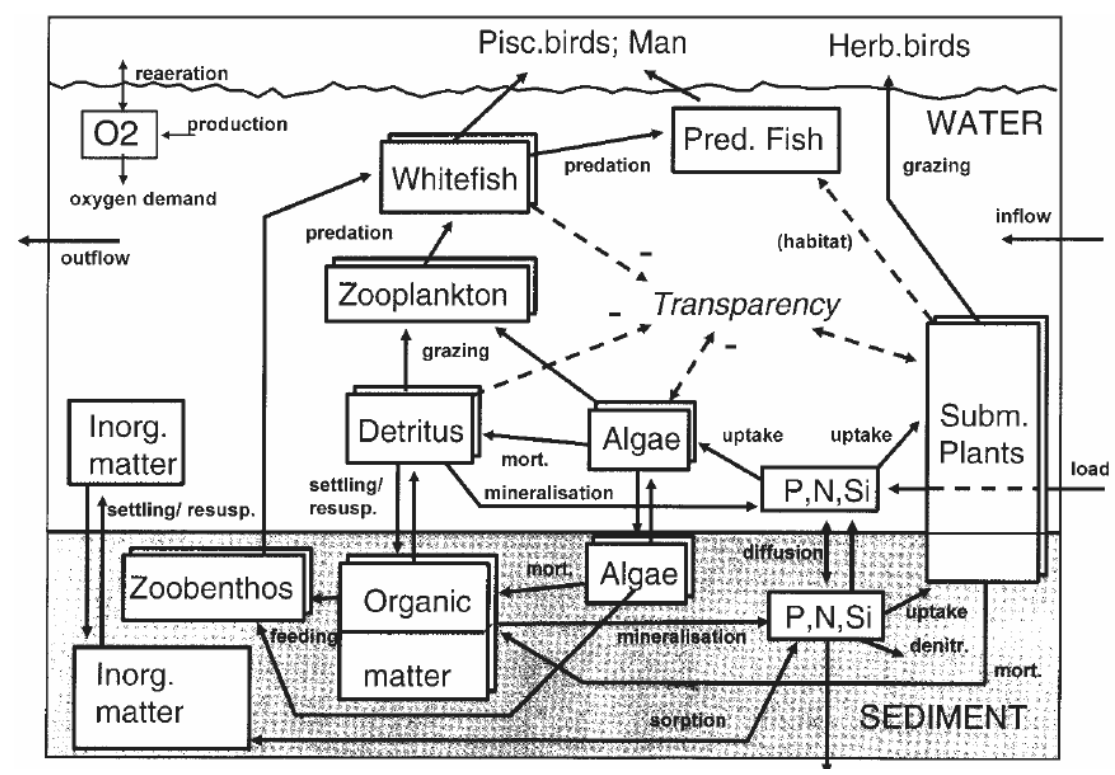

FIGURE 3. PCLake Model Structure 
depending on among others water depth, hydraulic loading rate, fetch, sediment type, marsh size and water temperature (which is related to climate scenarios). Output variables are e.g. concentrations of total $\mathrm{N}, \mathrm{P}$ and chlorophyll-a, and coverage of submerged plants (Janse, 1996; 2005).

Climate scenarios (year 2050) are derived from the WB21 scenarios of the Royal Netherlands Meteorological Institute, based on the SecondAssessment Report of the IPCC (Kors et al., 2000; Können, 2001). In Table 1 weather data is given for different climate scenarios. In the meantime new scenarios have been published (KNMI, 2006; IPCC, 2007): the expected temperature increase is even higher. both a macrophyte dominated clear and a phytoplankton dominated turbid state. A clear state is defined as chlorophyll-a $<50 \mu \mathrm{g} / \mathrm{l}$, a turbid state as chlorophyll-a $\geq 50 \mu \mathrm{g} / \mathrm{l}$.

The long term ecological changes were simulated by PCLake based on the results of the water and nutrient balance (1970-2004). The water and nutrient balance are adjusted to evaporation and precipitation according to the climate scenarios.

\section{RESULTS}

Calculated and measured discharges through inlet weir and outlet culvert are comparable (Fig. 4). Simulated and measured chloride concentrations

TABLE 1. Climate scenarios for 2050 compared to present (based on Kors et al., 2000). T - air temperature, Prec. - precipitation, Ev. - evaporation, $\mathrm{S}$ - summer, $\mathrm{W}$ - winter

\begin{tabular}{|l|c|c|c|c|c|}
\hline Scenario & $\mathrm{T}$ & Prec. S & Prec. W & Ev. S & Ev. W \\
\hline Low estimate wet & $+0.5 \%$ & $+0.5 \%$ & $+3 \%$ & $+4 \%$ & $+4 \%$ \\
\hline Central wet & $+1 \%$ & $+1 \%$ & $+6 \%$ & $+4 \%$ & $+4 \%$ \\
\hline High estimate wet & $+2 \%$ & $+2 \%$ & $+12 \%$ & $+8 \%$ & $+8 \%$ \\
\hline High estimate dry & $+2 \%$ & $-10 \%$ & $-10 \%$ & $+8 \%$ & $+8 \%$ \\
\hline
\end{tabular}

Two types of simulations have been done: one to determine critical loads and one to simulate long term ecological changes. The critical nutrient loads are determined by running PCLake with an adjusted water temperature for each climate scenario. The water temperature is calculated with air temperature, radiation, water depth, wind velocity and humidity. To determine critical load, the simulation period was set to 35 years. Phosphorus load was varied within a range of 0.01 to $0.17 \mathrm{mg} / \mathrm{m}^{2} \cdot \mathrm{d}$ in 13 steps for each scenario, starting from follow the same pattern as chloride concentrations (Fig. 5). We conclude that the water balance and the nutrient balance are sufficiently accurate for modelling. The water balance (Fig. 6) is dominated by precipitation and evaporation. In dry years the water composition can differ, because of inlet from Lake Loosdrecht.

The phosphorus load (Fig. 7) is determined mainly by water inlet from Lake Loosdrecht. In 1976 the external P-load was very high. From 1984 the external P-load dropped due to management measures. 


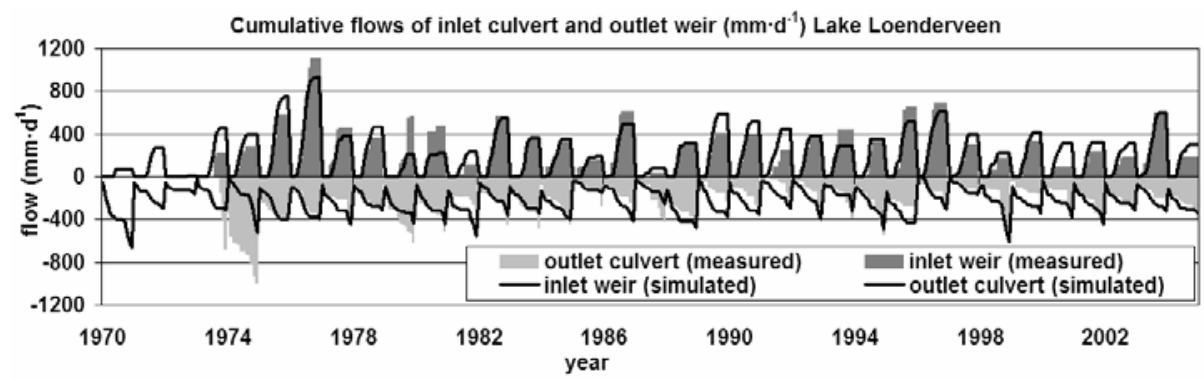

FIGURE 4. Measured and simulated cumulative flows $(\mathrm{mm})$ of Lake Loenderveen

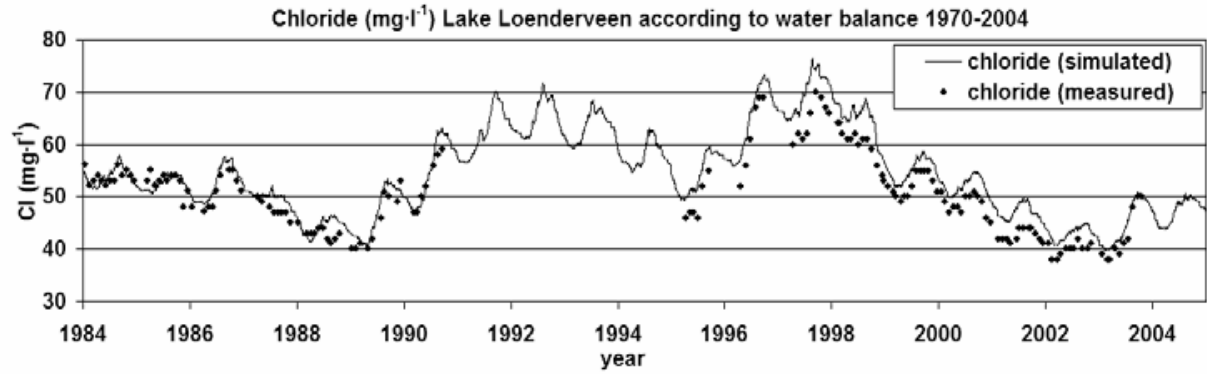

FIGURE 5. Measured and simulated chloride (mg/l) of Lake Loenderveen (1984-2004)

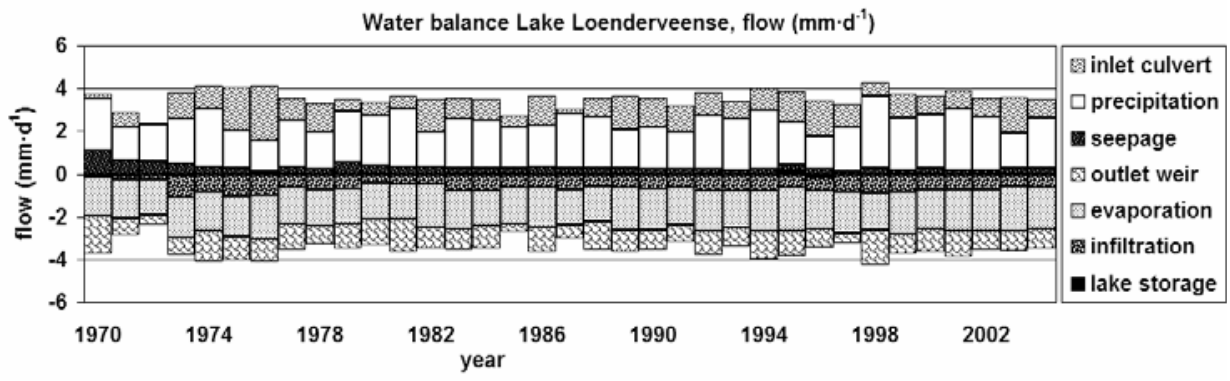

FIGURE 6. Water balance of Lake Loenderveen (1970-2004)

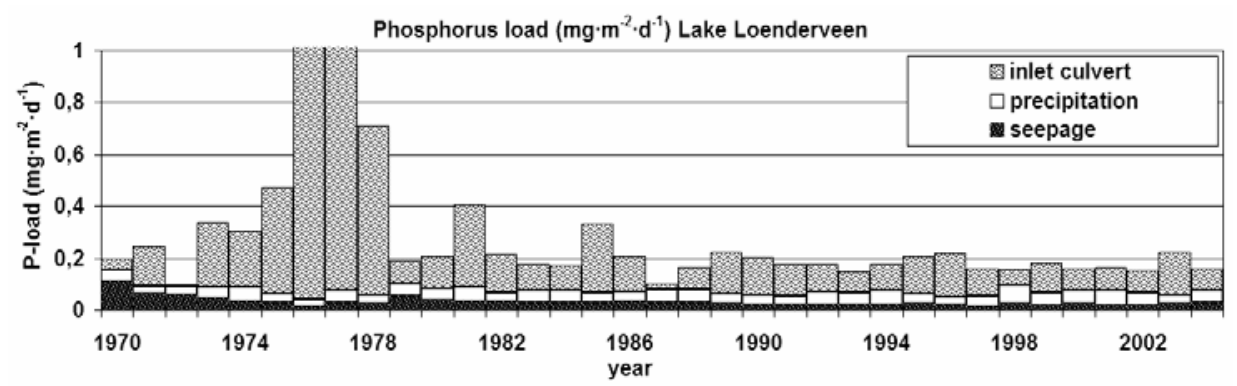

FIGURE 7. Phosphorus balance and phosphorus load of Lake Loenderveen (1970-2004) 
Critical P-loads: at present, the critical P-loads of Lake Loenderveen as estimated by PCLake are: 0.028 and $0.065 \mathrm{mg} / \mathrm{m}^{2} \cdot \mathrm{d}$ for $\mathrm{CNL}_{\text {oligo }}$ and $\mathrm{CNL}_{\mathrm{eu}}$ respectively. These values are very low compared to those for 'average' or 'most common' Dutch lakes as presented by Janse (2005) and Mooij et al. (2007): $\mathrm{CNL}_{\text {oligo }} 0.6-1.0 \mathrm{mg} / \mathrm{m}^{2} \cdot \mathrm{d}$ and $\mathrm{CNL}_{\text {eu }}$ $2-5 \mathrm{mg} \mathrm{P} / \mathrm{m}^{2} \cdot \mathrm{d}$. This can be explained by the low hydraulic loading rate, the high fetch, water depth and the high NPratio (Janse, 2005).

Long term simulation: according to chlorophyll (Fig. 8) three phases are distinguished: a clear water state before the high nutrient load (1970-1976), a shift (1977-1982) and a turbid state (1982-2004). PCLake simulated both clear and turbid state very well, so the critical P-loads are accurate enough for climate scenarios studies. However, the shift from the clear to the turbid state was simulated five years earlier than the observed shift according to chlorophyll.

The delayed response of the observed chlorophyll-a compared to the P-load can be explained by retention processes in the sediment. These temporary processes are to complex to simulate with PCLake. Beside that simulation results are comparable with observed changes. Thus, the methodology is useful for long term climate scenario studies.

As an effect of the different climate scenarios $\mathrm{CNL}_{\mathrm{eu}}$ decreases while $\mathrm{CNL}_{\text {oligo }}$ remains nearly constant (Fig. 9). This means that the ecological status will shift easier from the clear water state to the turbid state. Because temperature increase according to recent scenarios (KNMI, 2006; IPCC, 2007) is even higher, critical P-loads will decrease even more.

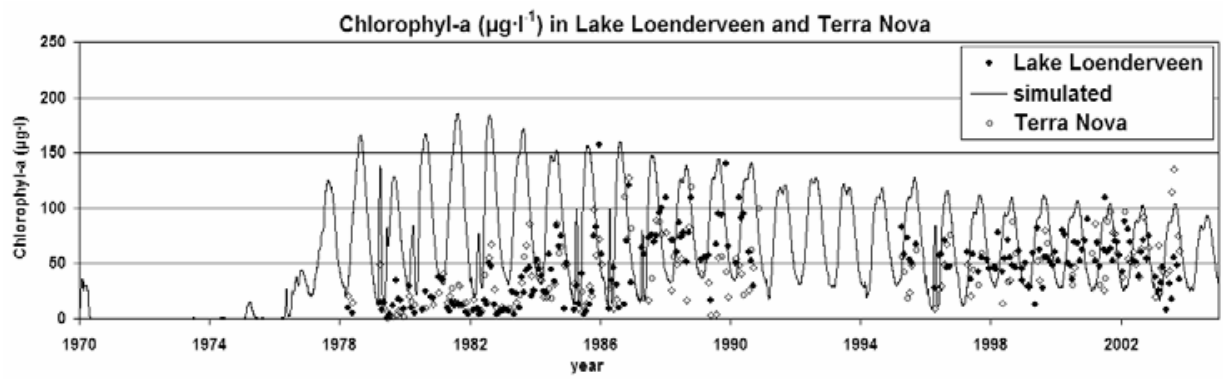

FIGURE 8. Measured (from 1977) and simulated (PCLake) chlorophyll-a (and ecological state)

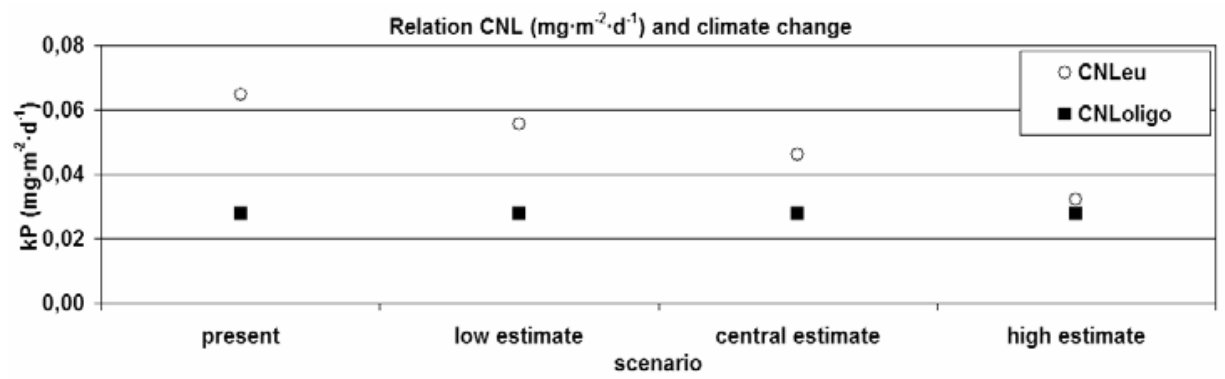

FIGURE 9. Critical nutrient (P) loads $\mathrm{CNL}_{\text {oligo }}$ and $\mathrm{CNL}_{\mathrm{eu}}$ (present and climate scenarios) 
The actual phosphorus load (Fig. $10)$ is much higher than both critical phosphorus loads. This explains why the lake remained turbid until 2004. All climate scenarios for 2050 will lead to an increase of the phosphorus load. Because the critical phosphorus load decrease, the turbid state becomes even more stable.

At the end of the simulation period all scenarios result in a turbid lake with a short clear water period in early spring. Compared to the present scenario, all scenarios for 2050 will lead to a decrease of the ecological status, as the chlorophyll-a concentration will be higher (Fig. 11).

The relatively small influence of climate change on the ecological functioning of Lake Loenderveen can be explained by the hydrological isolated position and the impact of the very high P-load in 1976. In less isolated lakes, like the Botshol Nature Reserve, for example phosphorus runoff from the adjacent grasslands will increase significantly as a result of climate change (Rip et al., 2007).

\section{CONCLUSIONS}

Climate change lead to changes in both environmental factors and ecosystem response. Hydraulic and nutrient load increase through increasing precipitation and evaporation. Because of water temperature related changing chemical and bacteriological processes and increasing growth rates of phytoplankton and submerged vegetation critical nutrient loads decrease.

The decrease of critical nutrient loads combined with an increase of the nutrient load might cause a clear lake to become

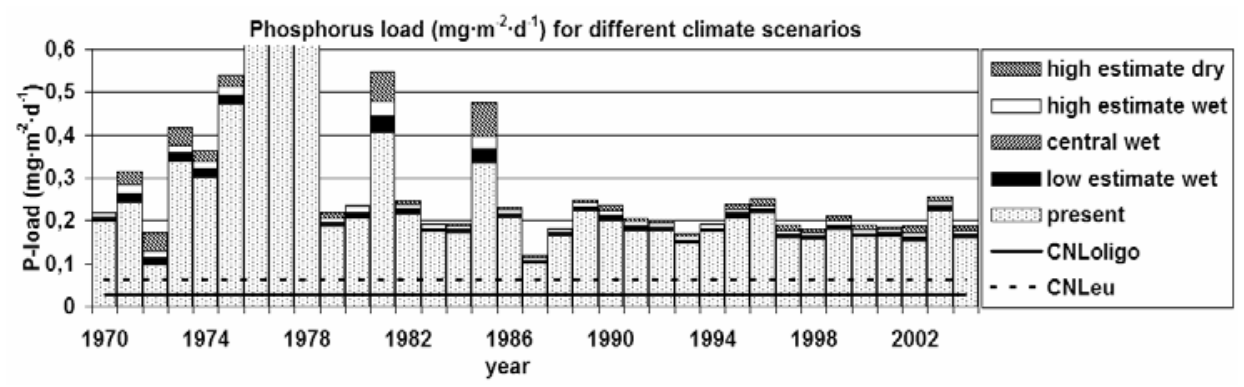

FIGURE 10. P-loads (cumulative) of present and climate scenarios compared to present CNL
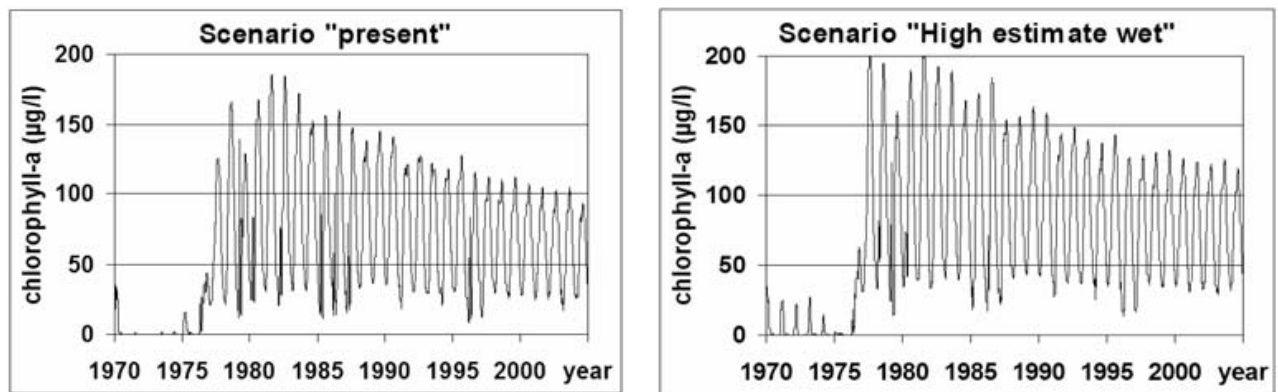

FIGURE 11. Simulated chlorophyll-a concentrations (present and climate scenario) 
turbid and hamper a return towards the clear state.

In Lake Loenderveen the result of climate change is a turbid state that is even more stable than the actual turbid state. The results of this study show that in the future more effort might be needed to reach the same ecological goals as a result of climate change.

The multidisciplinary approach presented in this study provides a useful and cost-effective method to study the potential effect of climate change on lake ecosystems. It's recommend that the effects of climate changes are included in the WFD processes to investigate the sustainability of the expensive measures (particularly nutrient load reduction) that will be taken the in next years.

\section{REFERENCES}

ALDENBERG T., JANSE J.H., KRAMER P.R.G. 1995: Fitting the dynamic lake model PCLake to a multi-lake survey through Bayesian statistics. Ecological Modelling, 78, 83-99.

BEST E.P.H., de VRIES D., REINS A. 1984: The macrophytes in the Loosdrecht Lakes: a story of their decline in the course of eutrophication. Verhandlungen der Internationale Vereinigung für Limnologie, 22, 868-875.

De LANGE W.J. 1991: A groundwater model for the Netherlands. RIZA, Lelystad.

DEKKER A.G., MALTHUS T.J., WIJNEN M.M., SEYHAN E. 1992: Remote sensing as a tool for assessing water quality in Loosdrecht Lakes. Hydrobiologia, 233, 137-159.

GOOGLE EARTH 2005: http://earth.google. com.

GLATI R.D. 1990: Zooplankton structure in the Loosdrecht lakes in relation to trophic status and recent restoration measures. Hydrobiologia, 191, 173-188.

GULATI R.D., van DONK E. 2002: Lakes in the Netherlands, their origin, eutrophication and restoration: stateof-the-art review. Hydrobiologia, 478, 73-106.

IPCC 2007: Climate Change 2007: The Physical Science Basis. Contribution of Working Group I to the Fourth Assessment Report of the Intergovernmental Panel on Climate Change [Solomon, S., D. Qin, M. Manning, Z. Chen, M. Marquis, K.B. Averyt, M. Tignor and H.L. Miller (eds.)] Cambridge University Press, Cambridge, United Kingdom and New York, NY, USA, 996 pp.

JANSE J.H. 1996: A model of nutrient dynamics in shallow lakes in relation to multiple stable states. Hydrobiologia 342-343 1-8.

JANSE J.H. 2005: Model studies on the eutrophication of shallow lakes and ditches. $\mathrm{PhD}$ thesis, Wageningen University.

KNMI 2006: KNMI Climate Change Scenarios 2006 for the Netherlands. KNMI Scientific Report, WR 2006-01.

KORS A.G., CLAESSEN F.A.M., WESSELING J.W., Können G.P. 2000: Scenario's externe krachten voor WB21. RIZA/WL and KNMI publication.

KÖNNEN G.P. 2001: Climate scenarios for impact studies in The Netherlands. KNMI, De Bilt.

MOOIJ W.M., HÜLSMANN S., DE SENERPOORT DOMIS L.N., NOLET B.A., BODELIER P.L.E., BOERS P.C.M., DIONISIO PIRES M.L., GONS H.J., IBELINGS B.W., NOORDHUID R., PORTIELJE R., WOLFSTEIN K., LAMMENS E.H.R.R. 2005: The impact of climate change on lakes in the Netherlands: a review. Aquatic Ecology, 39, 381-400.

MOOIJ W.M., JANSE J.H., DE SENERPONT DOMIS L.N., HÜLSMAN S., IBELINGS B.W. 2007: Predicting the effect of climate change on temperate 
shallow lakes with the ecosystem model PCLake. Hydrobiologia, 584, 443-454.

RIP W.J., OUBOTER M., LOS H.J. 2007: Impact of climatic fluctuations on Characeae biomass in a shallow, restored lake in the Netherlands. Hydrobiologia, 584, 415-424.

RYDING, S.O., FORSBERG C. 1977: Sediments as a nutrient source in shallow polluted lakes. In: H. Golterman (ed.), Interaction between sediments and fresh water. Dr. W. Junk, Den Haag, 227-235.

SCHEFFER M. 1998: Ecology of shallow lakes. Chapman \& Hall.

SCHEFFER M. 2001: Ecology of shallow lakes. Kluwer Academic Publishers, Dordrecht, Boston, London.

SCHEFFERM., HOSPER S.H., MEIJER M.L., MOSS B., JEPPESEN E. 1993: Alternative Equilibria in Shallow Lakes. Trends in Ecology \& Evolution, 8, 27-279.

Van LIERE L., JANSE J.H. 1992: Restoration and resilience to recovery of the Lake Loosdrecht ecosystem in relation to its phosphorus flow. Hydrobiologia, 233, 95-104.

VERAART J., WESTEIN E. 2005: De klimaatdimensie van de Kaderrchtlijn Water. Wageningen, Alterra.

Streszczenie: Możliwe skutki wptywu zmian klimatycznych na ekologiczne funkcjonowanie phytkich jezior, na przykładzie jeziora Loenderveen, Holandia. Ramowa Dyrektywa Wodna Unii Europejskiej wymaga, aby wszystkie wody (części wód) śródlądowe i przybrzeżne osiągnęły co najmniej dobry stan ekologiczny do roku 2015. Dobry stan ekologiczny w przypadku płytkich jezior może być scharakteryzowany poprzez wodę o dużej przezroczystości i wysokiej jakości, w której dominuje roślinność zanurzona. Charakter ekologicznej reakcji płytkich jezior na dopływ substancji biogennych w przeważającym stopniu zależy od cech morfologicznych i hydrologicznych tych jezior, takich jak: głębokość wody, czas retencji wody, zmiany stanów wody, typ dna itp. Te cechy określają wielkość krytycznego ładunku substancji biogennych, jaki może przyjąć dane jezioro bez konsekwencji związanych $\mathrm{z}$ obniże- niem jego stanu ekologicznego. W momencie, kiedy rzeczywisty ładunek substancji biogennych znajdujących się w wodach jeziora przekracza wartość ładunku krytycznego, jakość ekologiczna takiego jeziora maleje, prowadząc w rezultacie do zmętnienia wody oraz jej zdominowania przez glony. Zmiany klimatyczne mogą prowadzić do zmian zarówno w odniesieniu do czynników środowiskowych, jak i reakcji ekosystemów. Zaistnienie takiego typu zmian będzie miało, z pewnością, wpływ na stan ekologiczny. Do ilustracji możliwych efektów takich zmian wykorzystano i przedstawiono w niniejszym opracowaniu wyniki wielodyscyplinarnych badań, obejmujących badania hydrologiczne, geochemiczne i geologiczne, płytkiego jeziora pochodzenia torfowiskowego (Loenderveen). Przeprowadzono identyfikację oraz analizę ruchów (kierunki i przepływy) wód gruntowych oraz powierzchniowych, dynamiki zmian wielkości ładunków substancji biogennych oraz funkcjonowania ekosystemu, które zostały następnie wykorzystane i zastosowane w ekologicznym modelu jeziora (PCLake). Implementacja scenariuszy biorących pod uwagę potencjalne zmiany klimatyczne przeprowadzona została przez wprowadzenie zmian w wielkościach opadów, ewapotranspiracji oraz temperatury. Zmiany klimatyczne będą prowadzić do zwiększenia ładunków emitowanych substancji biogennych, przy jednoczesnym obniżeniu krytycznego ładunku substancji biogennych dla jezior. W konsekwencji jeziora będą łatwiej przechodziły ze stanu charakteryzującego się wodami przezroczystymi do stanów, gdzie wody będą mętne czyli łatwiej będzie następowało pogorszenie ich stanu ekologicznego.

\section{MS. received December 2007}

\section{Authors' addresses:}

Sebastiaan A. Schep

Witteveen+Bos, P.O. Box 233, 7400 AE Deventer, The Netherlands, s.schep@witteveenbos.nl

Gerard N.J. ter Heerdt, Maarten Ouboter Waternet, P.O. Box 8169, 1005 AD Amsterdam, The Netherlands, gerard.ter.heerdt@waternet.nl

Jan H. Janse

MNP/NLB (postbak 45), P.O. Box 303, $3720 \mathrm{AH}$ Bilthoven, The Netherlands JH.Janse@mnp.nl 